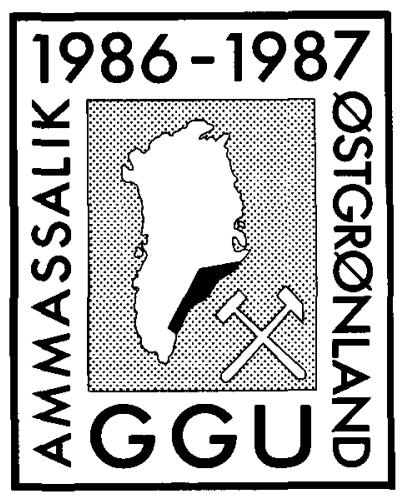

\title{
Reconnaissance $P, T$ studies of Proterozoic crustal evolution of the Ammassalik area, East Greenland
}

\author{
A. P. Nutman and C. R. L. Friend
}

\begin{abstract}
The Ammassalik area of East Greenland lies in the centre of a $300 \mathrm{~km}$ wide early Proterozoic mobile belt, dominated by Archaean gneisses and early Proterozoic metasediments. Regional Proterozoic synkinematic metamorphism was associated with crustal thickening by southerly-directed thrusting and isoclinal folding. Maximum $P, T$ conditions recorded during the regional metamorphism are found in the northern half of the mobile belt and are $9.5 \mathrm{kbar}$ (equivalent to $30 \mathrm{~km}$ burial) and $c$. $700^{\circ} \mathrm{C}$. Following some erosion and uplift, the late kinematic 1885 Ma Ammassalik Intrusive Complex (AIC) was intruded at pressures of $c .7 \mathrm{kbar}$ (equivalent to a depth of $20 \mathrm{~km}$ ). Temperatures in the metamorphic aureole of the AIC reached $800^{\circ} \mathrm{C}$. Following further erosion and uplift, post kinematic, c. 1575 Ma granite-dioritegabbro complexes were intruded, under pressures of $2.5 \mathrm{kbar}$ (equivalent to a depth of $8 \mathrm{~km}$ ).
\end{abstract}

\section{Introduction}

The Ammassalik area (fig. 1) lies in the centre of a $c$. $300 \mathrm{~km}$ wide WNW-ESE trending early Proterozoic mobile belt (Chadwick et al, this volume), previously correlated with the Nagssugtoqidian mobile belt of West Greenland (e.g. Bridgwater \& Myers, 1979; Myers, $1984,1987)$. The mobile belt is characterised by synkinematic amphibolite facies metamorphism, during and following tectonic thickening of the crust (e.g. Bridgwater \& Myers, 1979; Kalsbeek \& Nielsen, 1987; Chadwick et al., this volume).

The Proterozoic deformation affected an Archaean grey gneiss complex (cut by Proterozoic basic dykes) and early Proterozoic supracrustal rocks rich in pelitic material (Chadwick et al., this volume; Kalsbeek \& Taylor, this volume). The Ammassalik Intrusive Complex (AIC), formerly known as the 'Angmagssalik Charnockite Complex' (Bridgwater \& Myers, 1979) was intruded after thrusting, isoclinal folding and the peak of regional metamorphism. U-Pb zircon dating has yielded an age of $1886 \pm 2 \mathrm{Ma}$ (Hansen \& Kalsbeek, this volume). After intrusion of the AIC, open folds with axes trending WNW-ESE developed, and the margins of the AIC were locally sheared. After considerable erosion of the mobile belt had taken place, postkinematic granite-diorite-gabbro complexes were intruded at a high crustal level. These complexes crop out to the north of the AIC and west of Kitak island (e.g. Wager, 1934; Wright et al., 1973; Bridgwater \& Myers,
1979). Whole-rock Rb-Sr dating shows that these postkinematic complexes are c. 1575 Ma old (Pedersen \& Bridgwater, 1979; Taylor et al., 1984). The chronology as established during the field work in 1986 (Chadwick et al., this volume) is used here as a framework for our study.

This paper presents a reconnaissance petrographic and mineral-chemical study of metamorphic assemblages and information on pressure-temperature $(P, T)$ regimes; (a) during Proterozoic regional synkinematic metamorphism; (b) during intrusion of the late kinematic AIC; and (c) when the $c .1575$ Ma post-kinematic complexes were intruded. Such $P, T$ data are important in constraining models of the evolution of the whole Proterozoic mobile belt.

\section{Regional Proterozoic syn-kinematic metamorphism}

In areas of weak Proterozoic deformation, the regional Archaean grey gneiss complex is seen to have already been in a deformed, metamorphosed state prior to intrusion of early Proterozoic basic dykes (Wright et al., 1973; Bridgwater \& Myers, 1979). However, recrystallisation associated with post-basic dyke deformation has largely obscured the Archaean history of these rocks. They now consist of layered hornblende \pm biotite tonalitic-granitic gneisses. The basic dykes that cut the Archaean gneisses do not cut the AIC, and therefore they must be older than $1885 \mathrm{Ma}$. These dykes range 


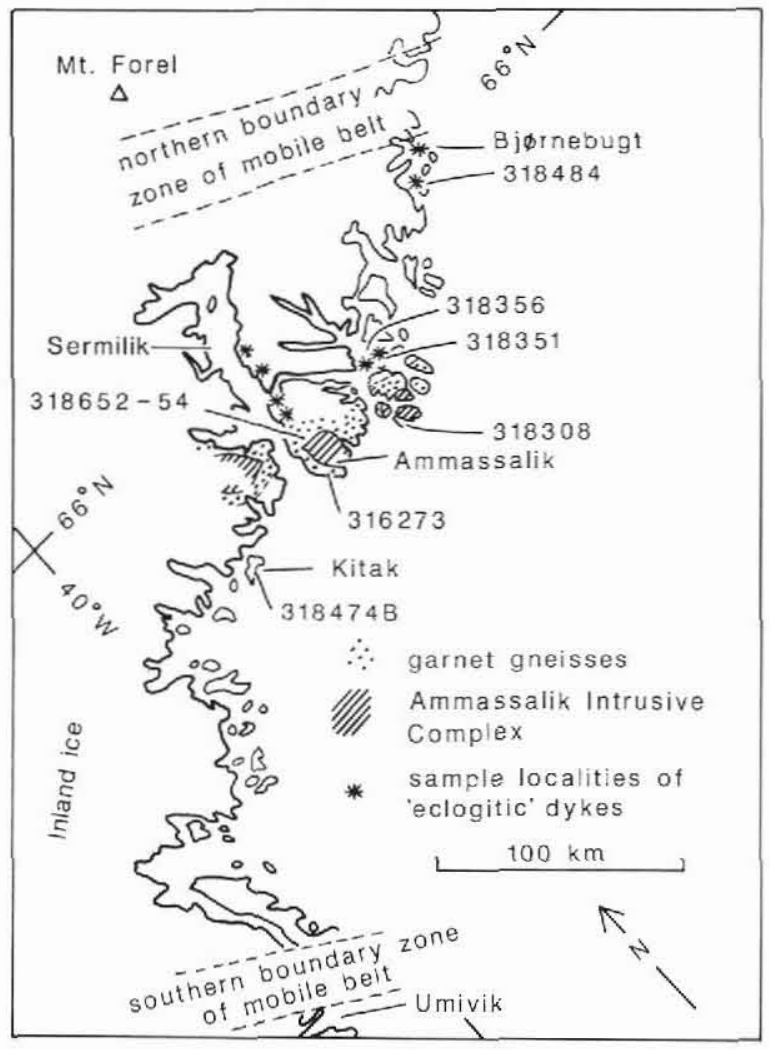

Fig. 1. Extent of the Proterozoic Ammassalik mobile belt of East Greenland and location of samples used in this study.

from meta-dolerites in which igneous textures are preserved, to strongly deformed amphibolites.

The major supracrustal units are dominated by metasediments (Friend \& Nutman, this volume, fig. 1), and are interpreted as a Proterozoic sequence intercalated by thrusting with the grey gneisses early in the development of the mobile belt (Chadwick et al., this volume). The intercalated grey gneisses and metasediments were then isoclinally folded, probably at greater depth in the crust, under a more 'ductile' regime. Strike slip displacements may also have been important (e.g. Chadwick et al., this volume).

Because they are Proterozoic in age the basic dykes explicitly provide information on Proterozoic metamorphic history. The metasediments in the study area have generally been so strongly deformed in the Proterozoic that, even if some of them are Archaean and not Proterozoic in age, it is highly unlikely that they preserve assemblages from Archaean metamorphic events.

The basic dykes have been heterogeneously deformed, such that they most commonly occur as strips and pods in the gneisses, and discordances are rare in the study area. Most of the dyke material is hornblende
+ plagioclase + quartz \pm garnet amphibolite with a marked $L S$ fabric. But the cores of some dykes, particularly in augen of lower deformation, preserve different earlier 'dry' metamorphic assemblages in different parts of the belt. In the northern part of the belt (fig. 1) there are yellow-green weathering 'eclogitic' cores in the dykes. The term 'eclogitic' is used for the assemblages in these dyke cores because it seems that the earliest metamorphic assemblage in them was garnet + omphacite (see below). These assemblages were previously noted by Wright et al. (1973) and D. Bridgwater and co-workers (D. Bridgwater, personal communication, 1987). The 'eclogitic' cores have been widely sampled in a $15 \mathrm{~km}$ wide zone to the north of the AIC, and reconnaissance shows that they occur at least as far north as Bjørnebugt on the outer coast, and at least half way northwards up Sermilik (fig. 1). In the southern-central part of the belt some dykes contain brown-weathering cores of garnetiferous dolerite. These are developed best on Kitak (fig. 1), and were previously noted by Wright et al. (1973) and D. Bridgwater and co-workers (D. Bridgwater, personal communication, 1987). In the southernmost part of the belt the earliest assemblage in the dykes is garnet-free dolerite. Unfortunately, comparable data are not available from dykes at the northern margin of the belt.

The cores of 'eclogitic' dykes consist of an early clinopyroxene + garnet assemblage overgrown by hornblende + plagioclase. The clinopyroxene is intergrown

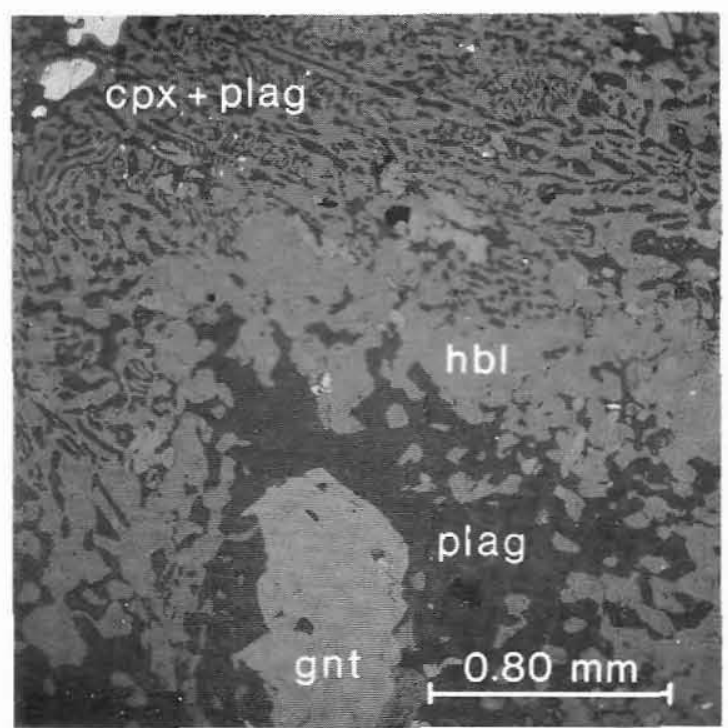

Fig. 2. Back-scatter image of 'eclogitic' dyke 318351. Fine intergrowths (cpx + plag) consist of clinopyroxene (light) and plagioclase (dark). Garnet (gnt) is mantled by hornblende (hbl) and plagioclase (plag), which separate it from the clinopyroxene + plagioclase intergrowths. 
Table 1. Representative energy dispersive quantitative analyses of a clinopyroxene containing plagioclase exsolution lamellae in an 'eclogitic' dyke

\begin{tabular}{lrcc}
\hline & $\begin{array}{c}\text { plagioclase } \\
\text { exsolution }\end{array}$ & $\begin{array}{c}\text { clinopyroxene } \\
\text { exsolution }\end{array}$ & $\begin{array}{c}\text { pre-exsolution } \\
\text { clinopyroxene }\end{array}$ \\
\hline $\mathrm{SiO}_{2}$ & 59.37 & 53.68 & 55.08 \\
$\mathrm{TiO}_{2}$ & 0.15 & 0.15 & 0.12 \\
$\mathrm{Al}_{2} \mathrm{O}_{3}$ & 23.66 & 1.23 & 11.02 \\
$\mathrm{FeO}$ & 0.24 & 10.27 & 6.78 \\
$\mathrm{MnO}$ & n.d. & 0.33 & n.d. \\
$\mathrm{MgO}$ & n.d. & 11.55 & 6.59 \\
$\mathrm{CaO}$ & 4.72 & 21.09 & 13.96 \\
$\mathrm{Na}_{2} \mathrm{O}$ & 11.92 & n.d. & 6.51 \\
$\mathrm{~K}_{2} \mathrm{O}$ & n.d. & n.d. & n.d. \\
& 100.06 & 98.30 & 100.06 \\
\hline
\end{tabular}

\section{GGU 318351}

n.d. not detected

Pre-exsolution composition of the clinopyroxene was determined by analysis of a $c .1 \mathrm{~mm}^{2}$ area of plagioclase and clinopyroxene exsolution of the type shown in fig. 2 .

with plagioclase (fig. 2). Similar clinopyroxene + plagioclase intergrowths have been found in eclogites in Norway and have been interpreted as having formed by exsolution of plagioclase from omphacitic clinopyroxene (Mysen \& Griffin, 1973; Jamtveit, 1987). In the 'eclogitic' dyke cores of the Ammassalik area, the present clinopyroxene is moderately aluminous and sodic, and the plagioclase is oligoclase (Table 1). Energy dispersive quantitative analysis of $1 \mathrm{~mm}^{2}$ areas of the clinopyroxene and plagioclase intergrowths in two dykes show that the original clinopyroxenes had $\mathrm{Na}_{2} \mathrm{O}$ contents of between 6.5 and $7.5 \mathrm{wt} \%$, and $\mathrm{Al}_{2} \mathrm{O}_{3}$ contents of between 10 and $11.5 \mathrm{wt} \%$ (Table 1); that is, they were omphacites containing 40 to $50 \%$ jadeite component. The early garnet + clinopyroxene + exsolved plagioclase assemblage is invariably partly replaced. The margins of some garnet grains have embayments (fig. 3) or partial coronas composed of oligoclase + orthopyroxene. This low An-content in the plagioclase suggests that the plagioclase + orthopyroxene intergrowths cannot have been produced by breakdown of the garnet alone, but must have involved reaction between the garnet and adjacent clinopyroxene + plagioclase intergrowths. Orthopyroxene + plagioclase development preceeded or was concurrent with production of hornblende + plagioclase \pm garnet at the expense of plagioclase + clinopyroxene + garnet \pm orthopyroxene of the earlier 'dry' assemblages. This gives rise to brownish hornblende + plagioclase coronas between garnet and

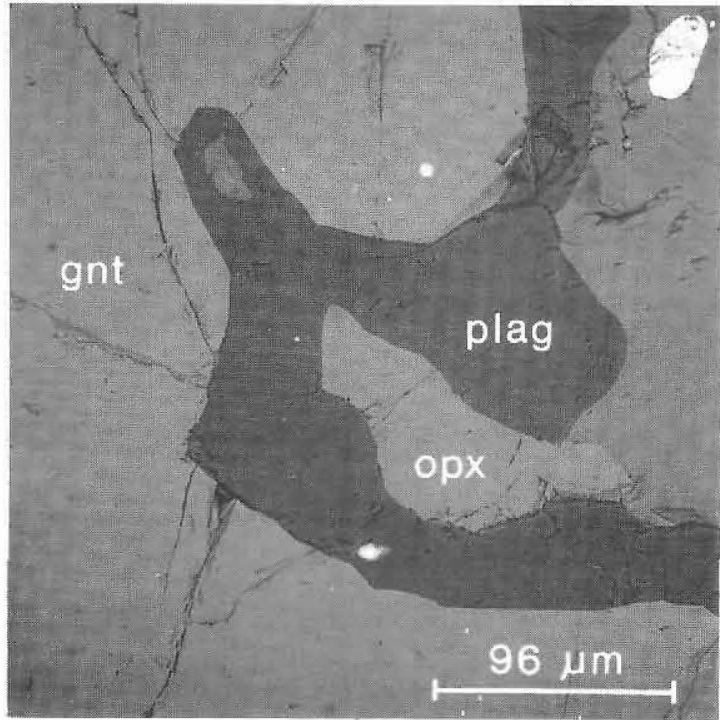

Fig. 3. Orthopyroxene (opx) and plagioclase (plag) developed at the expense of garnet (gnt) in 'eclogitic' dyke 318351.

clinopyroxene, and a general patchy overgrowth of the clinopyroxene by hornblende. Reactions giving rise to the assemblage hornblende + plagioclase + quartz \pm garnet have advanced furthest along dyke margins and also along vein networks through the 'eclogitic' cores, which shows that the supply of $\mathrm{H}_{2} \mathrm{O}$ from the adjacent gneisses is an important factor for these reactions. Combined with ductile deformation, the reactions resulted in the transformation of dykes into green hornblende + plagioclase + quartz \pm garnet amphibolites without any of the earlier 'eclogitic' assemblage preserved. Development of the hornblende + plagioclase + quartz \pm garnet assemblages is widely associated with development of strong $L S$ fabrics, showing that these assemblages developed during regional deformation, prior to intrusion of the late kinematic AIC.

South of the AIC (fig. 1) brown-weathering cores of the basic dykes display igneous textures and carry the assemblage plagioclase + garnet + clinopyroxene + quartz which is interpreted to be due to reaction between plagioclase and orthopyroxene in the original igneous assemblage. If this interpretation is correct. then the presence of the assemblage plagioclase + garnet + clinopyroxene + quartz would indicate that plagioclase was present in excess over orthopyroxene. Similar to the 'eclogitic' dykes to the north, these dykes display subsequent amphibolitisation associated with $\mathrm{H}_{2} \mathrm{O}$ penetration, eventually transforming them into fine-grained hornblende + plagioclase + quartz \pm garnet amphibolites with a strong $L S$ fabric.

Reconnaissance studies in the southernmost part of 
Table 2. $P-T$ estimates on mineral assemblages from the Ammassalik region

\begin{tabular}{|c|c|c|c|c|c|c|c|c|c|c|c|}
\hline Sample & 1 & 2 & 3 & 4 & 5 & 6 & 7 & 8 & 9 & 10 & 11 \\
\hline 318351 & & $620-690$ & $\begin{array}{c}620-720 \\
\text { at } 8.5\end{array}$ & & & & $\begin{array}{c}8.5-9.5 \\
\text { at } 3 \text { temps }\end{array}$ & & $\begin{array}{c}9.0-9.5 \\
\text { at } 3 \text { temps }\end{array}$ & & \\
\hline 318484 & & 700 & $\begin{array}{c}660-760 \\
\text { at } 8.5\end{array}$ & & & & $\begin{array}{c}8.0-9.0 \\
\text { at } 3 \text { temps }\end{array}$ & $\begin{array}{c}8.0-9.0 \\
\text { at } 3 \text { temps }\end{array}$ & & & \\
\hline $318474 \mathrm{~B}$ & & $650-660$ & & & & & $\begin{array}{c}7.0-8.5 \\
\text { at } 2 \text { temps }\end{array}$ & & & & \\
\hline 318308 & $830-850$ & & & & 480 & & $\begin{array}{c}7.5 \\
\text { at } 3 \text { temps }\end{array}$ & & & & \\
\hline 316254 & & & & & $\begin{array}{c}650-730 \\
\text { at } 7.5\end{array}$ & & & & & $\begin{array}{c}770-820 \\
\text { at } 7.5\end{array}$ & \\
\hline 316252 & & 550 & & & $\begin{array}{c}475 \\
\text { at } 7.5\end{array}$ & & & $\because$ & & $\begin{array}{c}740 \\
\text { at } 7.5\end{array}$ & \\
\hline 316253 & & & & $\begin{array}{c}730 \\
\text { at } 7.5\end{array}$ & $\begin{array}{c}560-590 \\
\text { at } 7.5\end{array}$ & & & & & $\begin{array}{c}750 \\
\text { at } 7.5\end{array}$ & \\
\hline 316273 & & & & $\begin{array}{c}710-780 \\
\text { at } 7.5\end{array}$ & & & & & & $\begin{array}{c}710-790 \\
\text { at } 7.5\end{array}$ & \\
\hline 318356 & & & & & $\begin{array}{c}650 \\
\text { at } 2.5\end{array}$ & $\begin{array}{c}590-610 \\
\text { at } 2.5\end{array}$ & & & & $\begin{array}{l}580 \\
\text { at } 2.5\end{array}$ & $\begin{array}{c}2.5 \\
\text { at } 600\end{array}$ \\
\hline
\end{tabular}

318351 and 318484 'eclogitic' dyke cores. 318474B garnetiferous dyke core. 318308 dioritic facies of AIC. 316254 partially melted metasediment, garnet gneiss aureole of AIC. 316252 and 316253 mafic lens in 316254. 316273 augen gneiss, close to AIC. 318356 metasediment close to post-kinematic intrusion. Location of samples is shown on fig. 1.

1. clinopyroxene-orthopyroxene thermometry (Wood \& Banno, 1973).

2. garnet-hornblende thermometry (Graham \& Powell, 1984).

3. garnet-clinopyroxene thermometry (Ellis \& Green, 1979, modified by Powell, 1985).

the mobile belt show that early garnet is not developed in the dykes, and synkinematic hydration of orthopyroxene + plagioclase + clinopyroxene igneous assemblages gives rise to hornblende + plagiclase + quartz \pm garnet amphibolites (Escher et al., this volume).

Table 2 presents $P, T$ estimates from the basic dykes using published thermobarometers. In general, $P, T$ estimates computed from analyses of rims of grains are considered more reliable than those computed using the cores of grains, as there is more certainty that they represent equilibrium assemblages. This is enforced by general consistency of results derived by using different thermobarometers (Table 2). $P, T$ estimates calculated from averaged core and rim compositions give a qualitative sense of the change of $P-T$ with time.
4. orthopyroxene-garnet thermometry (Harley, 1984).

5. garnet-biotite thermometry (Ferry \& Spear, 1978).

6. garnet-cordierite thermometry (Perchuk et al., 1985).

7. clinopyroxene-plagioclase barometry (Ellis, 1979).

8. clinopyroxene-plagioclase-garnet barometry (Newton \& Perkins, 1982 , with recommended +1.5 kbar correction).

9. orthopyroxene-plagioclase-garnet barometry (Newton \& Perkins, 1982, with recommended -0.5 kbar correction).

10. plagioclase-sillimanite-garnet barometry (Newton \& Hasselton, 1982).

11. garnet-cordierite barometry with $n_{\mathrm{H}_{2} \mathrm{O}}$ cordierite $=\mathrm{O}$ (Martignole \& Sisi, 1981).

Calculated using computer programs written by $F$. Mengel and A. P. Nutman. Temperatures in ${ }^{\circ} \mathrm{C}$; pressures in kbar.

Based on mineral rim analyses, the 'eclogitic' dykes in the northern part of the belt record temperatures of 660 to $760^{\circ} \mathrm{C}$ and pressures of 8 to $9.5 \mathrm{kbar}$ ( 318351 and 318484 , Table 2). The breakdown of garnet to give orthopyroxene + plagioclase indicates decompression. Also of note is that these dykes with their clinopyroxene containing exsolution lamellae of plagioclase, plot just on the low pressure side of the plagioclase-out curve for quartz tholeiitic compositions (fig. 4), also suggesting decompression. Hornblende-garnet thermometry on more deformed, amphibolitised dykes gives slightly lower temperatures, suggesting cooling during decompression. These results are shown in fig. 4 with the direction of the $P, T$ change shown. South of Kitak (fig. 1) mineral rim analyses from a garnet-bearing dyke core 


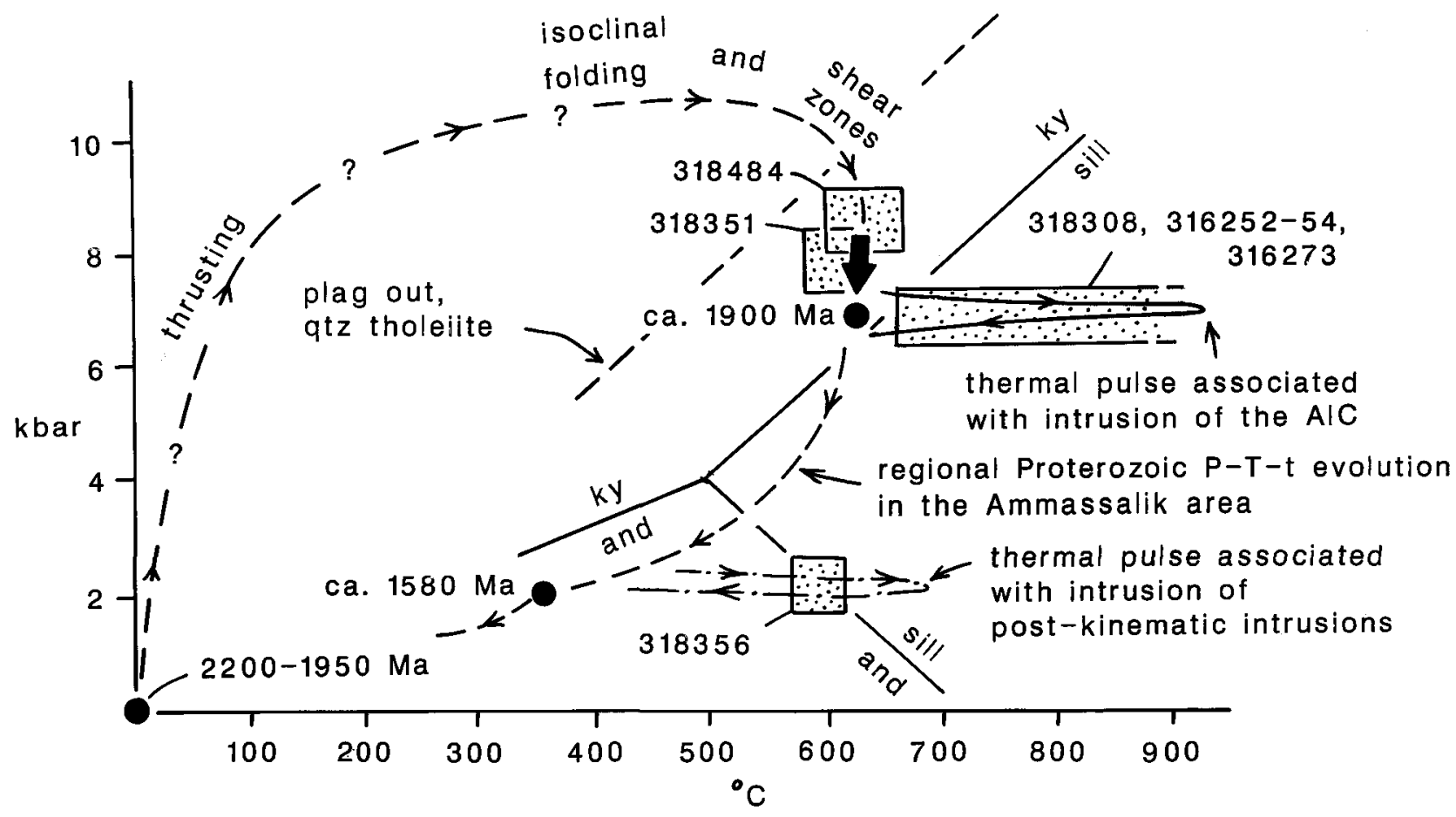

Fig. 4. $P, T$ diagram demonstrating $P, T$, time evolution in the Ammassalik area.

record 630 to $650^{\circ} \mathrm{C}$ and 7.5 to $8.5 \mathrm{kbar}(318474 \mathrm{~B}$, Table 2), slightly lower values than recorded by the 'eclogitic' cores of dykes in the northern part of the mobile belt.

Metasediments contain variations on the assemblage garnet + biotite + plagioclase + quartz + kyanite or sillimanite + graphite, suggesting moderate to high pressures during regional syn-kinematic amphibolite facies metamorphism, consistent with results obtained from the dykes (fig. 4).

\section{Contact metamorphism during intrusion of the Ammassalik Intrusive Complex}

The late kinematic AIC is dominated by dioritic rocks containing orthopyroxene + biotite + hornblende. Also found present are subordinate basic rocks carrying orthopyroxene + clinopyroxene and orthopyroxenebearing granitic rocks. The rocks in contact with the AIC consist of partially melted metasediments carrying sillimanite + garnet + biotite \pm orthopyroxene and orthopyroxene-bearing gneisses, which are correlated with the regional grey gneisses. Units of augen gneiss carrying garnet \pm orthopyroxene are found close to the AIC, and are interpreted as derived from accumulations of melt formed in the metasediments. Together these rocks form a group of garnet-rich gneisses representing a contact metamorphic aureole (Friend \& Nutman, this volume; Andersen et al., in press).
Thermobarometry on AIC rocks, augen gneisses and the partially melted metasediments and granulite facies gneisses of the garnet gneiss aureole, yield pressures of 6.5 to $7.5 \mathrm{kbar}$ (equivalent to $c$. $20 \mathrm{~km}$ burial) and temperatures between 550 and $900^{\circ} \mathrm{C}(318308,316254$, 316252,316253 and 316273 , Table 2, fig. 4). These results are in agreement with those reached independently by Andersen et al. (in press). The narrow range of $P$ estimates but wide range of $T$ estimates is what would be expected from an intrusion and its contact metamorphic aureole (fig. 4).

\section{Contact metamorphism during intrusion of the post-kinematic complexes}

The complexes are dominated by granite with subordinate diorite and gabbro. Contacts with country rocks are sharp, with evidence of stoping. The country rocks in contact with the complexes are not mobilised, and are hornfelsic. Miarolitic cavities in granites of some of the complexes indicate crystallisation at a low pressure. Paragneiss 318356 from close to a large body of post-kinematic gabbro and granite contains sillimanite + andalusite + kyanite + garnet + cordierite + biotite + plagioclase + quartz + hercynite + graphite . These minerals do not form a single assemblage. Instead it appears that a regional Proterozoic metamorphic assemblage of kyanite \pm sillimanite + garnet + 
biotite + plagioclase + quartz has been overprinted, with the growth of andalusite, cordierite, hercynite and possibly sillimanite at the expense of garnet, biotite and kyanite. Thermobarometric study of this sample yields pressures of c. $2.5 \mathrm{~kb}$ and temperatures of 580 to $650^{\circ} \mathrm{C}$ (318356, Table 2). These $P, T$ estimates are interpreted to reflect conditions during intrusion of the nearby postkinematic gabbro and granite complex at a high crustal level (7-8 $\mathrm{km}$ depth) at $c .1575 \mathrm{Ma}$ (fig. 4).

\section{$P, T$,time evolution in the Ammassalik area}

The data from the basic dykes suggest that pressures were greatest in the early tectonic development of the area. This is consistent with structural studies which provide evidence of early crustal thickening by tectonic intercalation of Proterozoic supracrustal and Archaean gneiss units (Chadwick et al., this volume). England \& Richardson (1977) and Spear et al. (1984) show that due to the low thermal conductivity of rocks, maximum heating is experienced in tectonically thickened crust millions of years after the thickening event, when erosion with resultant decompression has already taken its toll. Thus $P, T$ estimates on tectonically thickened regions comprising rocks that were in the upper crust prior to thrusting record approximately maximum $T$ but lower than maximum $P$ (Spear et al., 1984). When the temperature was highest, the mobile belt would have been weakest (e.g. Glazner \& Bartley, 1985), encouraging dissipation of any deviatory stresses by ductile deformation rather than brittle fracture. This would give rise to the observed regional amphibolite facies $L S$ tectonites, some time after initial crustal thickening due to thrusting.

The timing of the regional metamorphism is constrained between the likely maximum age of the metasediments (2200 Ma ?) and the age of the AIC (1885 $\mathrm{Ma}$ ). However, $\mathrm{Sm}-\mathrm{Nd}$ analysis of garnet, pyroxene and whole-rock samples for one 'eclogitic' dyke has yielded an age of $1820 \pm 20 \mathrm{Ma}$ (Kalsbeek \& Taylor, this volume). It is not clear at this time how this conflicting evidence should be interpreted. Assuming the England \& Richardson (1977) thermal model for tectonically thickened crust, the $P, T$ estimates presented above enable crude $P, T$, time paths for the mobile belt to be constructed. In rocks that were in the upper crust, thrusting caused rapid pressure increase followed by heating and 'setting-in' of regional metamorphic assem- blages during decompression at maximum temperatures, giving rise to a $P, T$, time path in the form of a clockwise loop. The Proterozoic metasediments which were near the surface prior to thrusting, would have followed this type of $P, T$,time path (fig. 4). The 'dry' early assemblages in the basic dykes (such as the 'eclogitic' assemblages) could have also formed following clockwise loop $P, T$,time paths (fig. 4). This would imply that their host units of Archaean gneisses were at high crustal levels prior to thrusting. Carswell \& Cuthbert (1986) show that eclogites (and garnet growth at the expense of plagioclase + orthopyroxene in basic rocks) can also be formed in 'dry' deep, crustal rocks, as a result of crustal thickening due to thrusting. These rocks suffer cooling together with pressure increase as a result of thrusting, bringing them into the stability field of eclogite. During erosion following crustal thickening, these rocks continue to cool, but undergo pressure decrease bringing them out of the stability field of eclogite again. If the 'eclogitic' assemblages were produced this way, it would imply that the host Archaean gneisses to the Proterozoic basic dykes were at deep crustal levels prior to thrusting. Irrespective of the origin of the early assemblages found in the 'dry' 'eclogitic' and 'garnet dolerite' cores, the parts of the mobile belt where there was the maximum degree of crustal thickening due to thrusting are exposed in the north, where the 'eclogitic' cores are found. Likewise, parts of the mobile belt where there was less crustal thickening due to thrusting are exposed in the south, where cores of basic dykes may develop garnet, but they have not been transformed into eclogite. The regional thickening in the belt might have been disrupted by later shear zones, such as on the north side of the AIC. Further studies of basic dykes from throughout the mobile belt are in progress to try and assess the early $P, T$ history of the rocks that were transformed into eclogites, regional variations in the degree of crustal thickening due to thrusting, and the importance (if any) of later shear zones on the distribution of metamorphic assemblages.

The $1885 \mathrm{Ma}$ AIC was intruded at a depth of $c .20$ $\mathrm{km}$, following some decompression due to erosion, and when most regional ductile deformation had already occurred (fig. 4). By 1575 Ma when the post-kinematic complexes were intruded the belt had cooled considerably and the presently exposed levels were at depths of only 7 to $8 \mathrm{~km}$ (fig. 4). 